\title{
PENGGUNAAN X BANNER DALAM PROMOSI LAYANAN PERPUSTAKAAN
}

\author{
Hana Silvana, Damayanty \\ Universitas Pendidikan Indonesia
}

\begin{abstract}
ABSTRAK
Penelitan ini bertujuan untuk mengetahui besarnya pengaruh tampilan promosi, isi pesan promosi, dan intensitas penyajian promosi layanan perpustakaan menggunakan Xbanner terhadap perilaku pemanfaatan layanan perpustakaan oleh mahasiswa di Perpustakaan Universitas pendidikan Indonesia, yang meliputi sub variabel perhatian, minat, keinginan, dan perilaku pemanfaatan layanan. Penelitian ini menggunakan metode kuantitatif. Dalam penelitian ini sampel yang diambil sebanyak 100 orang dari populasi sivitas akademika UPI yang tercatat sebagai anggota Perpustakaan UPI yang berkunjung ke Perpustakaan UPI pada minggu ke-2 bulan September yang berjumlah sebanyak 10.800 orang. Sampel ditentukan menggunakan rumus Taro Yamane serta teknik pengambilan sampel Stratified proportionate random sampling. Data dikumpulkan melalui teknik wawancara, angket, studi kepustakaan, dan observasi. Hipotesis diuji menggunakan analisis jalur. Hasil penelitian menunjukkan bahwa tampilan promosi, isi pesan promosi, dan intensitas penyajian promosi menggunakan Xbanner berpengaruh secara bersama-sama terhadap perhatian, minat, keinginan, dan kecenderungan berperilaku kearah positif, pengaruh terbesar yaitu terhadap keinginan. Perhatian dan kecenderungan berperilaku berkategori tinggi sedangkan untuk minat berkategori sedang.
\end{abstract}

Kata-kata Kunci: Promosi perpustakaan, Xbanner, perilaku pemanfaatan layanan perpustakaan

\section{THE USE OF X BANNER IN LIBRARY SERVICES PROMOTION}

\begin{abstract}
Research aims to find out the effect of promotional display, promotional message, and the intensity of promotional presentation of library services using Xbanner on library service utilization behavior by students at the library of Indonesia University of Education, which includes the sub-variables of attention, interest, desire, and behavior of service utilization. This study uses quantitative method. In this study, the sample taen from 100 people of UPI academicians registered as members of UPI Library visiting the library on the 2nd week of September, with as many as 10.800 people visiting. The samples were determined by using Taro Yamane formula and stratified proportion random sampling technique. The data collected through interview techniques, questionnaire, literature study, and observation. The hypothesis was tested by using path analysis. The results show that altogether, the display promotions, promotional message, and the intensity of promotional presentation services using Xbanner have significant effect on the behavior of library members of the Indonesia University of Education which consisted of the sub-variables of attention, interest, desire, and tendency to behave. The behavior changed in a positive direction, in which the most affected is desires, followed by attention, and the tendency to behave, which lies into high category and the interest which lies into medium category .
\end{abstract}

Keywords: Library promotion, Xbanner, behavior of library service utilization

Korespondensi: Hana Silvana, M.Si. Universitas Pendidikan Indonesia Jl. Dr. Setiabudhi No. 229 Bandung. Email: hanasilva@upi.edu 


\section{PENDAHULUAN}

Perkembangan ilmu pengetahuan, teknologi informasi, dan komunikasi dewasa ini telah membawa perubahan yang sangat pesat terhadap perkembangan layanan perpustakaan. Pelayanan informasi/ pelayanan perpustakaan merupakan suatu proses atau upaya penyebarluasan sumber- sumber informasi (buku dan non buku) kepada pengguna sehingga terjadi titik temu antara kebutuhan informasi pengguna dengan sumber informasi yang ada di perpustakaan. Layanan informasi di perpustakaan merupakan ujung tombak dalam penyelenggaraan kegiatan perpustakaan. Pelayanan perpustakaan ini merupakan sub sistem atau bagian dari keseluruhan kegiatan perpustakaan yang saling terkait dengan kegiatan lainnya seperti pengadaan, pengolahan, dan pemeliharaan bahan pustaka. Dalam struktur organisasi kerja perpustakaan, pelayanan perpustakaan terletak pada kegiatan penyebarluasan informasi (dissemination of information).

Adanya perkembangan

layanan perpustakaan karena kehadiran teknologi komputer di perpustakaan kini telah merubah sistem layanan perpustakaan menjadi layanan terotomasi, bahkan hadirnya internet di perpustakaan kini telah membawa perpustakaan menuju layanan perpustakaan secara digital. Adanya perkembangan perpustakaan tersebut menimbulkan beraneka ragam layanan di perpustakaan seperti: pelayanan sirkulasi secara mandiri, pelayanan referensi secara online, pelayanan informasi secara on-line, pelayanan informasi terseleksi dari koleksi e-journal, pelayanan komputer atau internet atau basis data, pelayanan informasi kilat, dan pelayanan khusus. Perkembangan iptek juga telah menyebabkan perpustakaan mengalami pergeseran paradigma. Paradigma baru perpustakaan yaitu perpustakaan adalah sesuatu yang tumbuh, hidup, dinamis, menawarkan hal-hal yang baru, produk layanannya selalu diperbaharui, serta dikemas sedemikian rupa, sehingga apa yang ditawarkan oleh perpustakaan akan menjadi penuh daya tarik dan menyenangkan, interaktif, edukatif, dan rekreatif bagi pengunjungnya. Pegawainya berpenampilan menarik, ramah, dan proaktif sehingga dapat memberikan pelayanan yang menyenangkan kepada penggunanya. Gedung atau ruang perpustakaan ditata dengan apik, sejuk, dan nyaman.

Tidak selamanya suatu bentuk layanan dapat diterima dengan cepat oleh pengguna, walaupun pada dasarnya layanan tersebut ditujukan untuk kepentingan mereka. Artinya, diperlukan suatu proses adaptasi atau bahkan pembelajaran. Salah satu jalan keluarnya agar layanan yang diadakan di perpustakaan dimanfaatkan oleh penggunanya yaitu keberadaan layanan serta cara pemanfaatannya perlu dikomunikasikan kepada para penggunanya. Upaya untuk memperkenalkan dan memasarkan jasa layanannya kepada pengguna perpustakaan yaitu melalui promosi layanan perpustakaan baik melalui media cetak maupun elektronik.

Promosi layanan merupakan penawaran jasa layanan informasi dimana promosi ini merupakan suatu proses komunikasi yang ditujukan untuk menawarkan kepada para pelanggan yang belum mengetahui keberadaan layanan atau juga untuk memberikan motivasi kepada mereka untuk menggunakan produk atau jasa layanan. Menurut Edinger (Mustafa, 2009: 5) mengemukakan bahwa promosi perpustakaan adalah kegiatan komunikasi dengan pemakai yang telah ada maupun yang belum ada tetapi potensial agar mereka tahu tentang pelayanan yang ada. Kemudian Mustafa (2009: 21) mengemukakan pengertian promosi sebagai berikut:

Promosi adalah mekanisme komunikasi persuasif pemasaran dengan memanfaatkan teknik-teknik hubungan masyarakat. Promosi merupakan forum pertukaran informasi antara organisasi dan konsumen dengan tujuan utama memberi informasi tentang produk atau jasa yang disediakan oleh organisasi, sekaligus membujuk konsumen untuk bereaksi terhadap produk atau jasa itu.

Reaksi konsumen terhadap promosi dapat muncul dalam berbagai bentuk, mulai dari tumbuhnya kesadaran atau sekedar mengetahui keberadaan produk atau jasa itu, sampai kepada tindakan membeli atau memanfaatkannya. Salah satu bentuk promosi layanan perpustakaan yang kini sedang marak digunakan yaitu promosi melalui media Xbanner. Promosi melalui media Xbanner yaitu penyampaian publikasi suatu produk atau jasa dengan menggunakan teknologi cetak dalam format poster yang biasa ditempel di dinding, dipasang pada dudukan yang ringan sehingga mudah dipindahkan, serta dalam format digital pada sebuah media web 


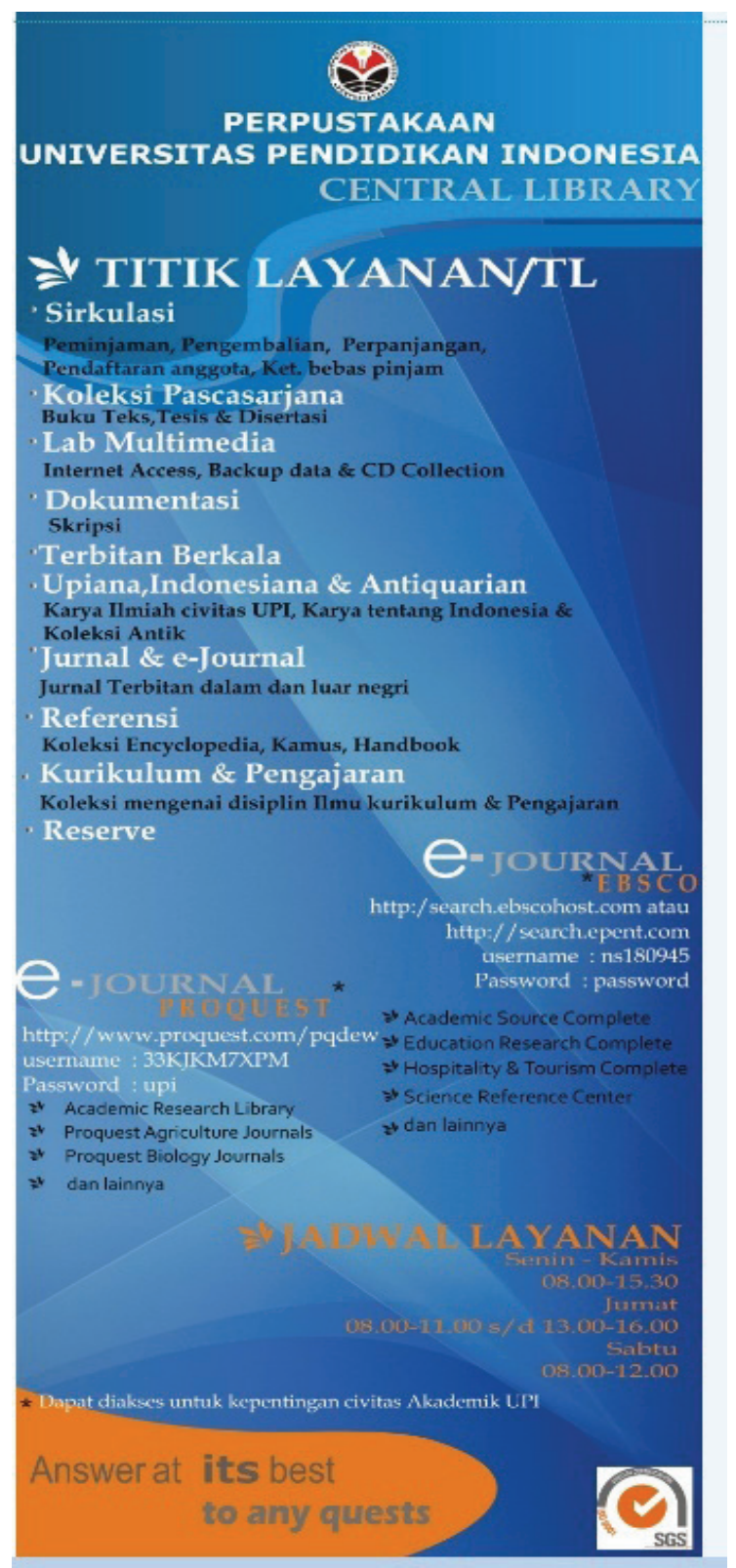

\section{Gambar 1 Tampilan Promosi layanan Perpustakaan UPI menggunakan Xbanner}

Sumber: Damayanty. 2012

atau blog atau media jejaring sosial.

Perpustakaan Universitas Pendidikan Indonesia (UPI) merupakan salah satu perpustakaan perguruan tinggi yang telah memanfaatkan media Xbanner untuk mempromosikan pelayanan dan programprogram perpustakaan yang dimilikinya. Media banner yang digunakan yaitu banner dalam format poster yang dipasang pada dudukan berbentuk $\mathrm{X}$ yang dikenal dengan banner $X$ atau Xbanner. Adapun promosi layanan yang dimuat melalui Xbanner di Perpustakaan UPI yaitu waktu layanan perpustakaan, jenis-jenis layanan perpustakaan seperti: layanan Sirkulasi, layanan Koleksi Pascasarjana, layanan Lab. Multimedia, layanan koleksi Dokumentasi (skripsi), Terbitan Berkala, Upiana, Indonesiana dan Antiquaria, Jurnal, Referensi, Kurikulum dan Pengajaran, Reserve, E-Journal EBSCO dan E-Journal Proquest.

Promosi layanan perpustakaan menggunakan Xbanner telah dilakukan oleh Perpustakaan UPI sejak bulan Januari tahun 2009. Promosi ini ditujukan untuk mengenalkan layanan-layanan yang tersedia di Perpustakaan UPI serta menjaring sivitas akademika UPI agar lebih banyak yang memanfaatkan layanan yang ada di Perpustakaan untuk menunjang 
aktivitas mereka dalam pelaksanaan pendidikan dan pengajaran, penelitian, dan sebagai salah satu sarana komunikasi ilmiah. Banner-banner promosi layanan Perpustakaan UPI ditempatkan di pintu masuk Perpustakaan UPI dan pintu masuk gedung di beberapa Fakultas yang ada di UPI.

Tampilan promosi layanan Perpustakaan UPI menggunakan media banner menggunakan teknik cetakan dengan bantuan komputer. Tampilan promosi layanan tersebut didesain dengan bentuk huruf dan latar belakang warna yang diperkirakan dapat menarik perhatian pembacanya. Tampilan promosi layanan Perpustakaan UPI menggunakan Xbanner dapat dilihat pada gambar 1 .

Pada promosi layanan Perpustakaan UPI menggunakan media Xbanner, tampilan promosi yang berisi pesan promosi yang dikomunikasikan kepada pengguna Perpustakaan UPI merupakan bagian yang penting. Sebagaimana halnya yang dikemukakan oleh Mustafa (2009: 22) sebagai berikut:

Bagian utama dalam suatu instrumen jasa layanan adalah pesan yang dikomunikasikan kepada konsumen atau pengguna melalui berbagai unsur yang terdapat dalam suatu kegiatan promosi. Pesan yang disampaikan dalam kegiatan promosi jasa layanan harus dapat menarik perhatian, menciptakan kesan, menimbulkan keinginan, dan memperoleh tanggapan.

Sejalan dengan pendapat tersebut Lupiyoadi (2008: 123) mengemukakan bahwa "Pesan yang dirancang perusahaan harus efektif, dimana idealnya suatu pesan harus mampu memberikan perhatian (attention-A), menarik (interest-I), membangkitkan keinginan (desire-D), dan menghasilkan tindakan (action-A), yang semuanya dikenal sebagai metode AIDA".

Hal ini sesuai dengan tujuan promosi yang dinyatakan oleh Jerome dan Andrew (Mustafa, 2009: 22) bahwa kegiatan promosi sedikitnya memiliki 4 macam tujuan, yaitu untuk menarik perhatian, untuk menciptakan kesan, untuk membangkitkan minat, dan untuk memperoleh tanggapan.

Sasaran dari promosi layanan menggunakan media banner ini yaitu seluruh sivitas akademika UPI. Adapun jumlah mahasiswa yang tercatat sebagai pengguna Perpustakaan UPI yaitu sekitar 30.000 orang. Promosi layanan Perpustakaan UPI ini merupakan salah satu langkah pihak manajemen Perpustakaan UPI untuk menginformasikan dan memperkenalkan jenis-jenis layanan yang ada di Perpustakaan UPI, membangkitkan keinginan untuk memanfaatkan layanan, dan membujuk para pengguna untuk menggunakan layanan yang ada di Perpustakaan UPI. Perpustakaan UPI berusaha agar promosi layanan Perpustakaan UPI menggunakan Xbanner menjadi stimulus yang disampaikan kepada sivitas akademika UPI, yang pada akhirnya sivitas akademika UPI yang telah mendapat stimulus tersebut diharapkan akan memanfaatkan jasa layanan yang dipromosikan sebagai bentuk dari respons terhadap stimulus. Teori yang mengkaji tentang stimulus dan respons manusia terhadap stimulus dikemukakan oleh Thorndike yang dikenal dengan Teori stimulus respons. Menurut pandangan Thorndike yang terdapat dalam Yusup (2009: 277), asumsi teori koneksionisme yaitu bahwa

"belajar merupakan proses hubungan dua unsur fisik dan mental secara bergabungan. Unit mental adalah sesuatu yang dirasakan, sedangkan unit fisik adalah stimulus dan respons. Secara khusus ia melihat bahwa belajar sebagai proses hubungan (komunikasi) antara unsur mental dan unsur fisik, unit fisik dengan unit fisik, dan mental dengan unit mental."

Selanjutnya dalam Yusup (2009: 278) dikemukakan sebagai berkut:

"Teori belajar dari Thorndike disebut juga S-R Bond, karena melalui pembiasaan, respons tertentu dihubungkan dengan stimulus tertentu. Pola hubungan ini bersifat biologis, yakni perubahan dalam sistem saraf. Belajar terjadi jika stimulus mendapatkan respons yang benar, dan respons yang benar diperoleh melalui tindakan merespons secara trial and error; mencoba, gagal, mencoba lagi, gagal lagi, sampai pada kali tertentu berhasil" (Yusup, 2009: 278).

Promosi layanan Perpustakaan UPI diharapkan dapat merubah perilaku pengguna potensial Perpustakaan UPI yang tadinya tidak tahu menjadi tahu, dan tahu namun belum pernah memanfaatkan layanan Perpustakaan UPI, berubah menjadi tahu dan mulai memanfaatkan layanan Perpustakaan UPI untuk memenuhi kebutuhan informasi dalam kaitannya dengan kegiatan belajar mengajar. Dalam kegiatan promosi layanan perpustakaan menggunakan media Xbanner, 
terpaan terus-menerus dari media banner yang dipajang akan menjadi stimulus bagi individu yang melihat Xbanner promosi tersebut, dan individu yang mendapatkan stimulus tersebut akan memberikan respons dengan melakukan tindakan (action) seperti yang diharapkan dari tujuan promosi, yaitu akan memanfaatkan atau menggunakan apa yang dipromosikan. Dari kegiatan promosi layanan perpustakaan UPI diharapkan layanan Perpustakaan UPI dapat dimanfaatkan oleh pengguna perpustakaan secara optimal.

Perubahan perilaku dari individu yang mendapat terpaan media sejalan dengan teori belajar sosial dari Albert Bandura. Pengertian belajar menurut teori belajar Bandura seperti yang dikemukakan dalam Yusup (2009: 284) adalah sebagai berikut:

"Belajar adalah proses perubahan perilaku yang dibentuk melalui umpan balik informatif yang dihasilkan oleh perilaku langsung individu dalam interaksinya dengan lingkungannya, misalnya melalui kegiatan melihat, mengamati, dan meniru orang lain di sekitarnya. ... teori belajar sosial memang cocok untuk menjelaskan pola perilaku langsung manusia dalam interaksinya dengan lingkungannya. Berarti di sini terjadi hubungan timbal balik antara manusia dengan aspek lingkungan".

Dari hasil pengamatan di Perpustakaan UPI diketahui bahwa masih ada titik layanan perpustakaan yang pemanfaatannya belum optimal, seperti Reserve dan Upiana, Indonesiana, dan Antiquaria. Adanya kenyataan tersebut menunjukkan bahwa promosi layanan Perpustakaan UPI perlu ditingkatkan. Selain itu diperlukan juga penelitian untuk melihat hasil dari pelaksanaan promosi layanan Perpustakaan menggunakan media Xbanner yang telah dilakukan Perpustakaan UPI.

Berdasarkan latar belakang yang telah dipaparkan di atas, sangat menarik untuk mengkaji tentang Pengaruh Promosi layanan menggunakan Xbanner terhadap pemanfaatan layanan oleh mahasiswa di Perpustakaan Universitas Pendidikan Indonesia.

Rumusan masalah dalam penelitian ini adalah "Seberapa besar pengaruh promosi layanan menggunakan Xbanner terhadap perilaku pemanfaatan layanan oleh mahasiswa di Perpustakaan Universitas Pendidikan Indonesia?"
Berdasarkan rumusan masalah tersebut, diperoleh identifikasi masalah penelitian sebagai berikut: (1) Seberapa besar pengaruh promosi layanan menggunakan Xbanner terhadap perhatian mahasiswa pada layanan di Perpustakaan Universitas Pendidikan Indonesia?, (2) Seberapa besar pengaruh promosi layanan menggunakan Xbanner terhadap minat mahasiswa pada layanan yang dipromosikan pada Xbanner di Perpustakaan Universitas Pendidikan Indonesia?, Seberapa besar pengaruh promosi layanan menggunakan Xbanner terhadap keinginan mahasiswa pada layanan yang dipromosikan pada Xbanner di Perpustakaan Universitas Pendidikan Indonesia?, (4) Seberapa besar pengaruh promosi layanan menggunakan Xbanner terhadap perilaku pemanfaatan mahasiswa pada layanan yang dipromosikan pada Xbanner di Perpustakaan Universitas Pendidikan Indonesia?

Adapun maksud dari penelitian yaitu untuk mendapatkan suatu gambaran mengenai berbagai aspek yang berkaitan dengan pengaruh promosi layanan menggunakan Xbanner terhadap perilaku pemanfaatan layanan oleh mahasiswa di Perpustakaan Universitas Pendidikan Indonesia.

Tujuan penelitian yaitu untuk mengetahui besar pengaruh promosi layanan menggunakan Xbanner terhadap perilaku pemanfaatan mahasiswa pada layanan yang dipromosikan pada Xbanner di Perpustakaan Universitas Pendidikan Indonesia.

Kegunaan teoritis penelitian yaitu hasil penelitian diharapkan dapat memberikan informasi ilmiah yang bermanfaat dalam upaya pemecahan masalah dalam pengembangan ilmu perpustakaan dan informasi. Khususnya yang berkaitan dengan pengaruh promosi layanan menggunakan Xbanner terhadap perilaku pemanfaatan layanan oleh mahasiswa di Perpustakaan Universitas Pendidikan Indonesia. Kegunaan praktis penelitian yaitu (1) Hasil dari penelitian diharapkan sebagai bahan masukan dalam meningkatkan pemanfaatan layanan di Perpustakaan UPI, (2) Bahan masukan bagi para pengambil kebijakan Perpustakaan dalam mempromosikan jasa layanan yang ada di perpustakaan untuk memenuhi kebutuhan pengguna sehingga pengguna merasa puas dengan jasa layanan yang ada, dan (3) Meningkatkan strategi promosi yang lebih baik 
dalam memasarkan jasa layanan yang ada di Perpustakaan UPI.

\section{METODE PENELITIAN}

Metode penelitian menurut Sugiyono (2002: 1) yaitu:

“...cara ilmiah untuk mendapatkan data dengan tujuan atau kegunaan tertentu. Cara ilmiah berarti kegiatan penelitian itu didasarkan pada ciri-ciri keilmuan, yaitu rasional, empirik, dan sistematik. Rasional, berarti kegiatan penelitian itu dilakukan dengan cara-cara yang masuk akal, sehingga terjangkau oleh penalaran manusia. Empirik berarti caracara yang dilakukan itu diamati oleh indera manusia, sehingga orang lain dapat mengamati dan mengetahui cara-cara yang digunakan. Sistematik artinya, proses yang digunakan dalam penelitian itu menggunakan langkahlangkah tertentu yang bersifat logis".

Metode pendekatan yang dipergunakan dalam penelitian ini adalah pendekatan kuantitatif, yaitu metode yang dipergunakan untuk mengukur, menyajikan, serta menganalisis data-data dari permasalahan yang diteliti, sehingga hasilnya dapat dipertanggungjawabkan untuk kepentingan lembaga dan kebutuhan masyarakat akan informasi dapat terpenuhi di masa yang akan datang. Menurut Masyhuri (2008: 13) penelitian kuantitatif diartikan sebagai berikut:

"Penelitian kuantitatif adalah penelitian yang tidak terlalu menitikberatkan pada kedalaman data, yang penting dapat merekam data sebanyak-banyaknya dari populasi yang luas. Pemecahan masalahnya didominasi oleh peran statistik. Pendekatan penelitian kuantitatif adalah penelitian yang identik dengan pendekatan deduktif, yaitu berangkat dari persoalan umum (teori) ke hal yang khusus sehingga penelitian ini harus ada landasan teorinya".

Jenis penelitian yang digunakan dalam penelitian ini yaitu jenis penelitian menurut tingkat ekplanasi untuk permasalahan asosiatif yang menggunakan hubungan kausal. Yang dimaksud dengan penelitian menurut tingkat eksplanasi disini adalah tingkat penjelasan, yaitu bagaimana variabel-variabel yang diteliti itu akan menjelaskan objek yang diteliti melalui data yang terkumpul. Sedangkan yang dimaksud dengan permasalahan asosiatif yaitu suatu pertanyaan penelitian yang bersifat perubahan struktur korporasi dan menghubungkan dua variabel atau lebih. Adapun yang dimaksud dengan hubungan kausal adalah "hubungan yang bersifat sebab akibat" (artinya ada variabel yang mempengaruhi atau variabel penyebab dan ada variabel yang dipengaruhi atau variabel akibat) (Sugiyono, 2002: 11, 36-37). Penelitian ini terdiri dari dua variabel, yaitu variabel $\mathrm{X}$ dan variabel Y. "Variabel penelitian adalah suatu atribut atau sifat atau nilai dari orang, objek atau kegiatan yang mempunyai variasi tertentu yang ditetapkan oleh peneliti untuk dipelajari dan ditarik kesimpulannya" (Sugiyono, 2002: 32). Variabel $X$ pada penelitian ini yaitu pengaruh promosi layanan perpustakaan menggunakan Xbanner, sedangkan variabel Y yaitu pemanfaatan layanan perpustakaan oleh mahasiswa di Perpustakaan Universitas Pendidikan Indonesia.

Selanjutnya, "populasi adalah wilayah generalisasi yang terdiri atas objek/ subjek yang mempunyai kualitas dan karakteristik tertentu yang ditetapkan oleh peneliti untuk dipelajari dan kemudian ditarik kesimpulannya" (Sugiyono, 2002: 72). Populasi dalam penelitian ini yaitu seluruh sivitas akademika UPI yang tercatat sebagai anggota Perpustakaan UPI yang berkunjung ke Perpustakaan UPI pada minggu ke-2 bulan September yang berjumlah sebanyak 10.800 orang. Penentuan jumlah responden selama satu minggu ini diasumsikan bahwa siklus kunjungan mahasiswa adalah 1 minggu sekali, waktu buka 6 hari tersebut akan memberikan kesempatan bagi pengguna setiap fakultas untuk menjadi responden, dan 1 minggu adalah waktu yang diperlukan untuk menyebarkan angket dan mendapatkan komposisi pengguna menurut statistik.

Teknik pengambilan sampel dalam penelitian ini menggunakan teknik penarikan sampel Stratified proportionate random sampling, yaitu komposisi anggota perpustakaan yang berkunjung ke Perpustakaan UPI pada bulan September minggu ke-2, distratifikasi berdasarkan fakultas.

Sampel dalam penelitian ini adalah sivitas akademika UPI yang tercatat sebagai anggota Perpustakaan UPI yang diambil dari populasi dan jumlahnya dihitung menggunakan rumus dari Taro Yamane sebagai berikut: 


$$
\begin{gathered}
r_{\text {hitung }}=\frac{n\left(\sum X\right)-\left(\sum X\right) \cdot\left(\sum Y\right)}{\sqrt{\left\{n \cdot \sum X^{2}-\left(\sum X\right)^{2}\right\} \cdot\left\{n \cdot \sum Y^{2}-\left(\sum Y\right)^{2}\right\}}} \\
n=\frac{N}{N \cdot d^{2}+1} \quad \text { (Riduwan, 2008a: 44) }
\end{gathered}
$$

Dimana:

$\mathrm{n}=$ Jumlah sampel,

$\mathrm{N}=$ Jumlah populasi,

$\mathrm{d}^{2}=$ presisi yang ditetapkan sebesar $10 \%$.

$$
n=\frac{10800}{10800 \cdot\left(0,1^{2}\right)+1}=\frac{10800}{108}=100 \text { orang }
$$

Jadi jumlah sampel yang diambil dalam penelitian ini yaitu sebanyak 100 orang.

Penelitian ini menggunakan beberapa teknik pengumpulan data antara lain yaitu teknik wawancara, teknik angket, studi kepustakaan, dan observasi. Untuk keperluan analisis kuantitatif, jawaban setiap item instrumen dalam penelitian ini menggunakan skala Likert dengan skor jawaban dari nilai 1 sampai 5 sebagai berikut: Sangat Setuju (SS) dengan skor 5, Setuju (S) dengan skor 4, Ragu-ragu (R) dengan skor 3, Tidak Setuju (TS) dengan skor 2, Sangat Tidak Setuju (STS) dengan skor 1. "Skala Likert digunakan untuk mengukur sikap, pendapat, dan persepsi seseorang atau sekelompok orang tentang fenomena sosial" (Sugiyono, 2002: 86). Untuk menguji tingkat validitas dan reliabilitas instrumen penelitian ini, angket diujicobakan kepada anggota Perpustakaan UPI yang tidak menjadi sampel penelitian dengan menggunakan responden sebanyak 25 orang. Setelah instrumen itu valid dan reliabel, baru digunakan untuk mengumpulkan data penelitian sesungguhnya di lapangan.

Untuk menguji validitas alat ukur, terlebih dahulu dicari harga korelasi antara bagianbagian dari alat ukur secara keseluruhan dengan cara mengkorelasikan setiap butir alat ukur dengan skor total yang merupakan jumlah tiap skor butir/ item, dengan rumus Pearson Product Moment (Riduwan, 2010: 80) yaitu:

Dimana:

$$
r_{\text {hitung }}=\text { Koefisien Korelasi }
$$

$$
\begin{aligned}
& \sum \mathbb{X}=\text { Jumlah Skor Item } \\
& \sum \mathbb{Z}=\text { Jumlah Skor Total (seluruh item) } \\
& n \quad=\text { Jumlah responden }
\end{aligned}
$$

Selanjutnya dilakukan analisis dengan mengkorelasikan masing-masing skor item dengan skor total dan mengoreksi nilai koefisien korelasi yang overestimasi. Dari hasil perhitungan akan diperoleh nilai koefisien korelasi $\left(r_{\text {hitung }}\right)$ antara skor item dengan skor total yang dapat digunakan untuk menguji validitas instrumen. Nilai minimum yang dianggap valid apabila nilai korelasi (r) untuk skor item dengan total skor variabel sebesar 0,3 . Untuk itu valid tidaknya instrumen dapat dinyatakan sebagai berikut: instrumen valid jika $r_{\text {hitung }} \geq 0,3$ dan tidak valid jika $r_{\text {hitung }}<0,3$.

Kemudian dilakukan uji reliabilitas yang digunakan untuk mengetahui konsistensi alat ukur. Apakah alat ukur yang digunakan dapat diandalkan dan tetap konsisten jika pengukuran tersebut diulang. Pengujian reliabilitas dalam penelitian ini menggunakan metode Cronbach's Alpha, yaitu menganalisis reliabilitas alat ukur dari satu kali pengukuran. Adapun rumus yang digunakan dalam metode Cronbach's Alpha (Riduwan, 2008a: 221) yaitu:

$$
r=\left[\frac{k}{k-1}\right] \cdot\left[1-\frac{\sum S_{i}}{S_{t}}\right], \text { dimana } r=\text { nilai }
$$

reliabilitas, $=$ jumlah varians skor tiap-tiap item, $S_{t}=$ varians total, dan $k=$ Jumlah item.

Selanjutnya hasil perhitungan nilai reliabilitas dibandingkan dengan koefisien pada tabel dimana batas minimum reliabilitas yang dapat diterima adalah koefisien positif dan di atas 0,7. Untuk itu reliabel tidaknya instrumen penelitian dapat dinyatakan sebagai berikut: Jika $r_{\text {alpha }}$ positif dan $\geq 0,7$, maka item penelitian tersebut reliabel, dan jika $r_{a l p h a}<0,7$, maka item penelitian tidak reliabel.

Teknik analisis data dalam penelitian ini berkenaan dengan perhitungan untuk menjawab rumusan masalah dan pengujian hipotesis yang diajukan. Adapun teknik analisis data dalam penelitian ini menggunakan path analysis (analisis jalur). Model path analysis digunakan untuk menganalisis "pola hubungan antar variabel dengan tujuan untuk mengetahui 


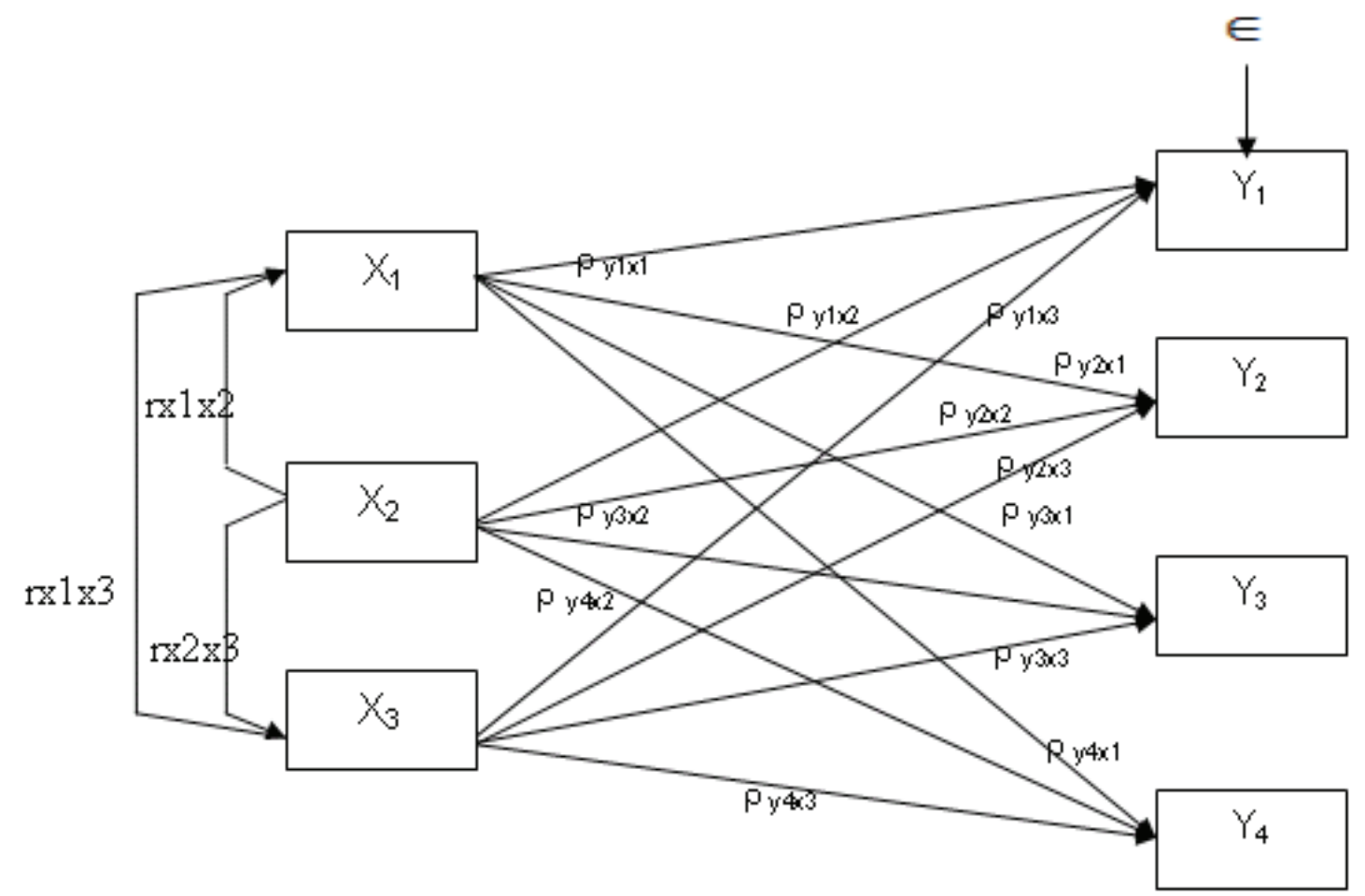

\section{Gambar 2 Model Hubungan antar Variabel dengan Diagram Jalur}

Sumber: Riduwan, 2008a: 6 (diolah oleh penulis)

pengaruh langsung maupun tidak langsung seperangkat variabel bebas (eksogen) terhadap variabel terikat (endogen)"(Riduwan, 2010: 140).

Penelitian ini mempunyai dua variabel yaitu variabel $\mathrm{X}$ (variabel bebas/ eksogen) dan variabel Y (variabel terikat/ endogen). Yang termasuk variabel $\mathrm{X}$ adalah tampilan promosi (X1), isi pesan promosi (X2), dan intensitas penyajian promosi (X3). Sedangkan variabel $\mathrm{Y}$ adalah Pemanfaatan layanan perpustakaan oleh mahasiswa di Perpustakaan Universitas Pendidikan Indonesia.

Jenis angket yang digunakan dalam penelitian ini adalah angket tertutup dengan menggunakan skala ordinal yang berpedoman pada Ordinal Summated Rating, yaitu lima alternatif jawaban 1,2,3,4,5 dan setiap nilai yang diperoleh merupakan indikator untuk variabel bebas $(X)$, yaitu $X_{1}, X_{2}$ dan $X_{3}$ serta variabel terikat (Y). Dalam analisis jalur data yang diperoleh yang berskala ordinal dikonversi ke bentuk data interval dengan menggunakan Method of Successive Interval (MSI). Selanjutnya dibuat model struktur hubungan kausal antar variabel yang lazim disebut dengan diagram jalur. Contoh model hubungan antar variabel dengan diagram jalur dapat dilihat pada gambar 2 .

Pengolahan data dilakukan dengan menggunakan komputer melalui program SPSS (Statistic Product and Service Solutions) versi 18. Adapun hipotesis umum penelitian ini dirumuskan sebagai berikut:

$\mathrm{H}_{\mathrm{o}}$ : Tidak terdapat pengaruh antara promosi layanan menggunakan Xbanner terhadap perilaku pemanfaatan layanan oleh mahasiswa di Perpustakaan Universitas Pendidikan Indonesia.

$\mathrm{H}_{1:}$ Terdapat pengaruh antara promosi layanan menggunakan Xbanner terhadap perilaku pemanfaatan layanan oleh mahasiswa di Perpustakaan Universitas Pendidikan Indonesia.

\section{HASIL DAN PEMBAHASAN}

Teori S-R yang digunakan sangat sesuai untuk diterapkan dalam penelitian tentang pengaruh promosi layanan menggunakan Xbanner terhadap perilaku pemanfaatan layanan oleh mahasiswa di Perpustakaan Universitas Pendidikan Indonesia. Teori S-R singkatan dari Stimulus-Respons bersumber dari psikologi. 
Karena teori ini mengkaji tentang stimulus, dan respons manusia terhadap stimulus, maka teori S-R ini dapat dikatakan sebagai turunan dari grand theory yaitu teori psikologi behaviorisme yang sama-sama menganalisis perilaku manusia. Teori S-R ini dikemukan oleh Thorndike yang disebut juga dengan koneksionisme dimana menurut teori ini proses hubungan antara stimulus dan respons bersifat langsung. Menurut pandangan Thorndike yang terdapat dalam Yusup (2009: 277), asumsi teori koneksionisme yaitu:

"bahwa belajar merupakan proses hubungan dua unsur fisik dan mental secara bergabungan. Unit mental adalah sesuatu yang dirasakan, sedangkan unit fisik adalah stimulus dan respons. Secara khusus ia melihat bahwa belajar sebagai proses hubungan (komunikasi) antara unsur mental dan unsur fisik, unit fisik dengan unit fisik, dan mental dengan unit mental."

Selanjutnya dalam Yusup (2009: 278) dikemukakan sebagai berkut:

"Teori belajar dari Thorndike disebut juga S-R Bond, karena melalui pembiasaan, respons tertentu dihubungkan dengan stimulus tertentu. Pola hubungan ini bersifat biologis, yakni perubahan dalam sistem saraf. Belajar terjadi jika stimulus mendapatkan respons yang benar, dan respons yang benar diperoleh melalui tindakan merespons secara trial and error; mencoba, gagal, mencoba lagi, gagal lagi, sampai pada kali tertentu berhasil."

Bila dikaji dengan teori S-R, promosi layanan menggunakan Xbanner dipandang sebagai stimulus (rangsangan) yang disampaikan kepada mahasiswa. Melalui pembiasaan yaitu dengan pemajangan promosi layanan menggunakan Xbanner dalam jangka waktu yang lama (dari tahun 2009 sampai tahun 2012), mahasiswa yang melihat Xbanner promosi layanan akan terstimulasi dan diperkirakan akan memberikan respons sesuai yang diharapkan. Respons yang diharapkan dari stimulasi terus menerus tersebut yaitu perilaku pemanfaatan layanan perpustakan oleh mahasiswa secara optimal.

Selanjutnya, penelitian ini dikaji pula dengan menggunakan teori belajar sosial. Teori belajar sosial yang dikembangkan oleh Albert Bandura menggambarkan gabungan antara teori belajar behavioristik dengan penguatan dan psikologi kognitif, dengan prinsip modifikasi perilaku (Yusup, 2009: 284). Pengertian belajar menurut teori belajar Bandura seperti yang dikemukakan dalam Yusup (2009: 284) adalah sebagai berikut:

"Belajar adalah proses perubahan perilaku yang dibentuk melalui umpan balik informatif yang dihasilkan oleh perilaku langsung individu dalam interaksinya dengan lingkungannya, misalnya melalui kegiatan melihat, mengamati, dan meniru orang lain di sekitarnya. ... teori belajar sosial memang cocok untuk menjelaskan pola perilaku langsung manusia dalam interaksinya dengan lingkungannya. Berarti di sini terjadi hubungan timbal balik antara manusia dengan aspek lingkungan".

Teori belajar sosial dapat menjelaskan bahwa berbagai macam media yang menerpa individu berfungsi sebagai stimulus yang akan menimbulkan perubahan prilaku individu tersebut. Dalam kegiatan promosi layanan perpustakaan menggunakan media Xbanner, terpaan terus-menerus dari media banner yang dipajang akan menjadi stimulus bagi individu yang melihat Xbanner promosi tersebut, dan individu yang mendapatkan stimulus tersebut akan mememberikan respons dengan melakukan tindakan (action) seperti yang diharapkan dari tujuan promosi, yaitu akan memanfaatkan atau menggunakan apa yang dipromosikan. Tindakan individu yang telah terkena terpaan pesan promosi misalnya berupa perilaku pemanfaatan layanan yang dipromosikan.

Bila dikaitkan dengan penelitian maka dapat diuraikan tampilan pesan promosi dan isi pesan serta intensitas penyajian promosi pada x-banner merupakan terpaan media promosi. Kemudian, proses penerimaan informasi yang tersaji pada promosi melalui Xbanner oleh anggota Perpustakaan UPI adalah dalam bentuk respons kognitif, respons afektif, dan respons konatif/ perilaku. Setelah terjadi terpaan pesan media promosi serta pengolahan informasi dalam diri penerima terpaan pesan media promosi, akan timbul perilaku pada diri mereka (anggota Perpustakaan UPI) yaitu berupa tindakan memanfaatkan layanan perpustakaan. Aspek kognitif seperti perubahan pendapat, sedangkan aspek afektif seperti perasaan kesukaan. Tahap selanjutnya yaitu timbulnya 
suatu tindakan/ perilaku menggunakan sesuatu karena ada informasi yang menerpa. Perubahan pada aspek kognitif, afektif, dan perilaku tersebut bila dikaitkan dengan tujuan komunikasi yang efektif/ model AIDA dari Saez (1993: 55) yaitu berupa timbulnya perhatian (Awareness/Attention) pada layanan di Perpustakaan UPI yang dipromosikan, timbulnya rasa berminat (Interest) menggunakan layanan Perpustakaan UPI yang dipromosikan, timbulnya keinginan (Desire) untuk mengunjungi perpustakaan dan menggunakan layanan di Perpustakaan UPI yang dipromosikan, dan timbul tindakan (Action) untuk mengunjungi Perpustakaan UPI dan memanfaatkan layanan di Perpustakaan UPI yang dipromosikan.

Perhatian menurut Mowen (2002: 97) adalah "alokasi kapasitas kognitif ke sebuah objek atau tugas sehingga informasi secara sadar dapat diproses". Aspek perhatian pada layanan Xbanner UPI dalam penelitian ini berupa pengetahuan tentang letak Xbanner layanan, pengetahuan tentang layanan Perpustakaan UPI, dan pengetahuan tentang fitur layanan Perpustakaan pada Xbanner. Aspek minat dan keinginan dalam konteks perilaku pemanfaatan layanan merupakan aspek afeksi (perasaan). Aspek minat pada penelitian ini menunjukkan rasa tertarik/ tidak tertarik terhadap layanan Xbanner UPI serta rasa berminat atau tidak berminat menggunakan layanan yang dipromosikan pada Xbanner UPI. Aspek keinginan dalam penelitian ini menunjukkan keinginan mengunjungi layanan yang dipromosikan pada Xbanner UPI dan keinginan menggunakan layanan perpustakaan UPI.

Sedangkan untuk aspek perilaku dalam penelitian ini berupa tindakan mengujungi Perpustakaan UPI dari mahasiswa sebagai sivitas akademika UPI dan tindakan menggunakan layanan Perpustakaan UPI mahasiswa sebagai sivitas akademika UPI.

Berdasarkan tabel nilai skor variabel $\mathrm{X}$ dan Y, diperoleh besar persentase seluruh tanggapan responden terhadap variabel $\mathrm{X}$ dan $\mathrm{Y}$ sebanyak $76,18 \%$. Secara umum responden memberikan tanggapan yang baik terhadap pernyataan variabel $X$ yang terdiri dari sub variabel $\mathrm{X}_{1}$ (Tampilan Penyajian Promosi), $\mathrm{X}_{2}$ (Isi Pesan Promosi), dan $\mathrm{X}_{3}$ (Intensitas Penyajian Promosi), dan pernyataan variabel $Y$ yang terdiri dari sub variabel $\mathrm{Y}_{1}$ (Perhatian), $\mathrm{Y}_{2}$ (Minat), $\mathrm{Y}_{3}$ (Keinginan), $\mathrm{Y}_{4}$ (perilaku pemanfaatan). Bila dilihat dalam garis interval, tanggapan responden yang memiliki skor sebesar 6857 berada pada kategori tinggi.

Selanjutnya dalam pengujian hipotesis diperoleh hasil yaitu secara bersama-sama ketiga sub variabel promosi layanan perpustakaan menggunakan Xbanner (tampilan penyajian promosi, isi pesan promosi, dan intensitas penyajian promosi) memberikan kontribusi (pengaruh) sebesar 40,82\% (nilai $\mathrm{R}^{2}$ ) dalam membentuk perhatian mahasiswa pada Xbanner layanan perpustakaan di Universitas Pendidikan Indonesia. Isi pesan promosi memberikan kontribusi (pengaruh) yang paling besar dalam membentuk perhatian mahasiswa pada Xbanner layanan perpustakaan di Universitas Pendidikan Indonesia. Isi pesan promosi yang terdapat pada tampilan promosi menggunakan Xbanner merupakan bagian yang penting dalam promosi, karena pesan tersebut merupakan sesuatu akan dikomunikasikan kepada pengguna Perpustakaan UPI. Sebagaimana halnya yang dikemukakan oleh Mustafa (2009: 22) sebagai berikut:

Bagian utama dalam suatu instrumen jasa layanan adalah pesan yang dikomunikasikan kepada konsumen atau pengguna melalui berbagai unsur yang terdapat dalam suatu kegiatan promosi. Pesan yang disampaikan dalam kegiatan promosi jasa layanan harus dapat menarik perhatian, menciptakan kesan, menimbulkan keinginan, dan memperoleh tanggapan.

Sejalan dengan pendapat tersebut Lupiyoadi (2008: 123) mengemukakan bahwa "pesan yang dirancang perusahaan harus efektif, dimana idealnya suatu pesan harus mampu memberikan perhatian (attention-A), menarik (interest-I), membangkitkan keinginan (desire-D), dan menghasilkan tindakan (action-A), yang semuanya dikenal sebagai metode AIDA".

Isi pesan promosi yang memiliki pengaruh paling besar dalam membentuk perhatian mahasiswa pada Xbanner layanan menunjukkan bahwa isi pesan promosi pada Xbanner layanan Perpustakaan UPI yang ditampilkan dalam bentuk tulisan, kata-kata, gambar telah cukup baik dan efektif dalam menarik perhatian mahasiswa pada Xbanner layanan.

Secara bersama-sama ketiga sub variabel 
Tabel Hasil Pengaruh Promosi X Banner pada Layanan dan Pemanfaatan Perpustakaan

Pengaruh Promosi Xbanner pada layanan perpustakaan
Pemanfaatan Layanan Perpustakaan Oleh Mahasiswa

\begin{tabular}{ccccccc}
\hline X1 & X2 & X3 & Y1 & Y2 & Y3 & Y4 \\
\hline $\begin{array}{c}\text { Tampilan } \\
\text { Penyajian } \\
\text { Promosi }\end{array}$ & $\begin{array}{c}\text { Isi Pesan } \\
\text { Promosi }\end{array}$ & $\begin{array}{c}\text { Intensitas } \\
\text { Penyajian } \\
\text { Promosi }\end{array}$ & Perhatian & Minat & Keinginan & Perilaku \\
\hline & $\mathbf{2 3 , 4 1 \%}$ & & $\mathbf{4 0 , 8 2} \%$ & $\mathbf{2 3 , 4 1 \%}$ & $\mathbf{4 8 , 4 9 \%}$ & $\mathbf{7 6 , 1 8 \%}$ \\
\hline
\end{tabular}

promosi layanan perpustakaan menggunakan Xbanner (tampilan penyajian promosi, isi pesan promosi dan intensitas penyajian promosi) memberikan kontribusi (pengaruh) sebesar 23,41\% (nilai $\mathrm{R}^{2}$ ) dalam membentuk minat mahasiswa pada Xbanner layanan perpustakaan di Universitas Pendidikan Indonesia. Intensitas penyajian promosi memberikan kontribusi (pengaruh) yang paling besar dalam membentuk minat mahasiswa pada Xbanner layanan perpustakaan di Universitas Pendidikan Indonesia

Secara bersama-sama ketiga sub variabel promosi layanan perpustakaan menggunakan Xbanner (tampilan penyajian promosi, isi pesan promosi dan intensitas penyajian promosi) memberikan kontribusi (pengaruh) sebesar 48,49\% (nilai $\mathrm{R}^{2}$ ) dalam membentuk keinginan mahasiswa pada Xbanner layanan perpustakaan di Universitas Pendidikan Indonesia. Intensitas penyajian promosi memberikan kontribusi (pengaruh) yang paling besar dalam membentuk keinginan mahasiswa pada Xbanner layanan perpustakaan di Universitas Pendidikan Indonesia.

Secara bersama-sama ketiga sub variabel promosi layanan perpustakaan menggunakan Xbanner (tampilan penyajian promosi, isi pesan promosi dan intensitas penyajian promosi) memberikan kontribusi (pengaruh) sebesar 40,69\% (nilai $\mathrm{R}^{2}$ ) dalam membentuk perilaku mahasiswa pada pemanfaatan layanan perpustakaan di Universitas Pendidikan Indonesia. Intensitas penyajian promosi memberikan kontribusi (pengaruh) yang paling besar dalam membentuk perilaku mahasiswa pada pemanfaatan layanan perpustakaan di Universitas Pendidikan Indonesia.

Hasil penelitian menunjukkan bahwa intensitas penyajian pesan promosi pada
Xbanner layanan Perpustakaan UPI memberikan pengaruh yang paling besar dalam membentuk minat, keinginan, dan perilaku mahasiswa pada pemanfaatan layanan perpustakaan. Intensitas penyajian pesan promosi berkaitan dengan frekuensi penyajian pesan promosi. Menurut Effendy (1989) frekuensi diartikan sebagai "kekerapan sesuatu dalam waktuwaktu tertentu" (Effendy, 1989: 147). Penyajian promosi menggunakan Xbanner di Perpustakaan UPI, dengan frekuensi setiap hari cukup efektif untuk mempengaruhi minat, keinginan, dan perilaku mahasiswa pada pemanfaatan layanan perpustakaan. Frekuensi penyajian promosi yang tinggi yang menerpa khalayak akan memudahkan khalayak mengenal bahkan mengingat pesan promosi yang diperolehnya. Tampilan penyajian promosi, isi pesan promosi dan intensitas penyajian promosi perpustakaan menggunakaan Xbanner yang dilakukan Perpustakaan UPI telah memberikan pengaruh dalam membentuk perhatian, minat, keinginan, dan perilaku mahasiswa pada pemanfaatan layanan perpustakaan. Promosi yang telah dilakukan Perpustakaan UPI tersebut telah diarahkan sesuai dengan tujuan promosi yaitu memberitahu, membujuk, dan merubah perilaku audiens. Hal ini seperti yang dikemukakan oleh Basu S. dalam Wira (1996) yang dikutip Suryati (1998: 21), promosi bertujuan untuk:

"Memodifikasi tingkah laku - promosi berusaha mengubah pikiran konsumen. Perusahaan sebagai pemberi informasi atas barang/jasa yang dihasilkan selalu berusaha untuk memberikan kesan baik pada pasar konsumen; 2) Memberitahu - kegiatan pasar juga dapat ditujukan untuk memberitahu produk yang dihasilkan perusahaan kepada masyarakat, tujuan pasar yang bersifat informatif ini penting 
bagi masyarakat untuk dapat membantu dalam mengambil keputusan untuk memilih produk atau jasa mana yang sebaiknya dibeli; 3) Membujuk - untuk mendorong orang agar bersedia membeli barang dan jasa yang dihasilkan perusahaan. Membujuk pelanggan sasaran untuk menentukan pilihan merk, mendorong pembeli untuk belanja saat itu juga dan mendorong pembeli untuk menerima kunjungan pemasar; 4) Mengingatkan bertujuan untuk mengingatkan kembali dan dilakukan untuk memperhatikan konsumen yang telah ada dan mengingatkan pembeli akan tempat-tempat penjualan produk/ jasa tersebut".

Hasil dari penelitian tentang Pengaruh promosi layanan perpustakaan menggunakan Xbanner (tampilan penyajian promosi, isi pesan promosi dan intensitas penyajian promosi) memberikan kontribusi terhadap perilaku pemanfaatan layanan oleh mahasiswa di perpustakaan Universitas Pendidikan Indonesia dengan matrik sebagai berikut:

\section{SIMPULAN DAN SARAN}

Dari hasil penelitian yang dilakukan, dapat disimpulkan bahwa secara bersama-sama terdapat pengaruh yang signifikan dari ketiga sub variabel promosi layanan perpustakaan menggunakan Xbanner (tampilan penyajian promosi, isi pesan promosi, dan intensitas penyajian promosi) terhadap perhatian mahasiswa pada Xbanner layanan perpustakaan di Universitas Pendidikan Indonesia. Secara bersama-sama terdapat pengaruh yang signifikan dari ketiga sub variabel promosi layanan perpustakaan menggunakan Xbanner (tampilan penyajian promosi, isi pesan promosi, dan intensitas penyajian promosi) terhadap minat mahasiswa pada Xbanner layanan perpustakaan di Universitas Pendidikan Indonesia. Secara bersama-sama terdapat pengaruh yang signifikan dari ketiga sub variabel promosi layanan perpustakaan menggunakan Xbanner (tampilan penyajian promosi, isi pesan promosi dan intensitas penyajian promosi) terhadap keinginan mahasiswa menggunakan layanan perpustakaan yang dipromosikan pada Xbanner di Universitas Pendidikan Indonesia. Secara bersama-sama terdapat pengaruh yang signifikan dari ketiga sub variabel promosi layanan perpustakaan menggunakan Xbanner (tampilan penyajian promosi, isi pesan promosi dan intensitas penyajian promosi) terhadap perilaku mahasiswa pada pemanfaatan layanan perpustakaan di Universitas Pendidikan Indonesia.

Adapun saran bagi Perpustakaan UPI yaitu sebaiknya isi pesan promosi layanan menggunakan Xbanner menggunakan kalimat pesanyang bersifat lebih persuasifagar perhatian, minat, keinginan, dan perilaku pemustaka pada pemanfaatan layanan perpustakaan lebih besar. Selain itu sebaiknya Perpustakaan UPI mengembangkan SDM khusus untuk menangani promosi perpustakaan agar promosi layanan perpustakaan lebih terprogram, dan beberapa jasa layanan yang pemanfaatannya belum optimal dapat dipromosikan secara lebih aktif.

\section{DAFTAR PUSTAKA}

Damayanty. (2011). Laporan perkembangan koleksi perpustakaan UPI bulan Desember Th. 2011. Bandung: Perpustakaan Universitas Pendidikan Indonesia.

Effendy, O. U. (1989). Kamus komunikasi. Bandung: Bandar Maju.

Indonesia. Departemen Pendidikan Nasional. (2008). Kamus besar bahasa Indonesia pusat bahasa. Jakarta: Gramedia.

Lupiyoadi, R. (2008). Manajemen pemasaran jasa. Jakarta: Salemba Empat.

Masyhuri. (2008). Metodologi penelitian: pendekatan praktis dan aplikatif. Bandung: Refika Aditama.

Mowen, J. C. (2002). Perilaku konsumen. Jakarta: Erlangga.

Mustafa, B. (2009). Promosi jasa perpustakaan: buku materi pokok PUST 2254/2 SKS/ MODUL: 1. Jakarta: Universitas Terbuka.

Riduwan. (2008a). Cara menggunakan dan memakai analisis jalur (path analysis). Bandung: Alfabeta. . (2008b). Metode dan teknik menyusun tesis. Bandung: Alfabeta. . (2008c). Skala pengukuran variabelvariabel penelitian. Bandung: Alfabeta.

. (2010). Pengantar statistika untuk penelitian pendidikan, sosial, ekonomi, komunikasi, dan bisnis. Bandung: Alfabeta.

Saez, E. E. (1993). Marketing concepts for libraries and information services. London: 
Library Association Publishing.

Sugiyono. (2002). Metode penelitian bisnis. Bandung: Alfabeta.

Suryati, D. (1998). Manajemen dan teknik promosi jasa perpustakaan: komitmen dan pemahaman (kasus di tiga perpustakaan). Tesis. Jakarta: Universitas Indonesia.

Yusup, P. M.(2009). Ilmu informasi, komunikasi, dan kepustakaan. Jakarta: Bumi Aksara. 